\title{
Another kind of mountains: seamounts
}

\author{
Marina MANEA ${ }^{1,2,3}$ \\ ${ }^{1}$ Laboratorio de Geodinamica Computacional, Centro de Geociencias, Universidad Nacional Autonoma de Mexico, \\ ${ }^{2}$ Institute of Astronomy of the Romanian Academy, \\ ${ }^{3}$ Center for Risk Studies, Spatial Modeling, Terrestrial and Coastal System Dynamics, University of Bucharest, \\ marina@geociencias.unam.mx
}

\begin{abstract}
Some of the most prominent features on the earth surface are the mountain ranges, but, under the sea surface, an entire new universe is worth to be studied. In this article, seamounts around the world are examined in a first attempt to classify them from the point of view of their geodynamical relevance. A special attention will be given to the seamounts positioned in the vicinity of subduction zones. This classification will be used later for numerical modeling their behavior once these seamounts enter into subduction. Also, the present state-of-the-art of the seamounts related knowledge is briefly presented.
\end{abstract}

Keywords: seamounts, geodynamical perspective, subduction zone

\section{INTRODUCTION}

Humans have been always fascinated with heights. In every culture around the world, the mountains were seen as gods and goddesses and they inspired many legends. Fiercer they were, the better. For Greeks, mount Olympus was not only one of the tallest mountains in Europe with its impressive 16 peaks, but also was the center of the Universe and the house of Gods (Fox, 1994). In Mexico, Popocatepetl (The Smoking Mountain) and Iztacihuatl (The Sleeping Woman) volcanoes inspired beautiful legends first written down by Pittman (1954), a scholar in nahuatl dialect. In Romania, almost every mountain peak from the Carpathians has a legend and fantastic stories transmitted from generation to generation, marking the connection between humans and the surrounding geography (Densusianu, 1910; Eliade, 1978; Coatu, 1986). Later, humans climbed, measured, classified and tried to conquer them. Sometime they succeeded, sometimes they failed, but this continuous enchantment remained. Nowadays, the mountains continue to be our ultimate fascination and many questions arouse: How did they form? What is their composition, their uplift or erosional rates? Are they volcanoes, or a product of compressional forces? etc. Anyhow, they can be observed and explored easily. When we talk about the longest mountain range, we usually think immediately at the Andean Mountain Range or the Andean Cordillera, as it is known (aprox $7000 \mathrm{~km}$ in length). When we talk about the tallest mountain peak, we immediately think about the Mount Everest with its official height of $8848 \mathrm{~m}$, even though the latest estimation gives a value of $8844 \mathrm{~m}$. But, we have to mention that this is the height measured above the sea level. What is the result when we eliminate completely the seawater? The answer is quite simple, as seen in Figure 1: the undersea features seem to be by far better represented and the bathymetric map unravels all the amazing structures under the sea level. Some of these features represent divergent tectonic plate margins. One example is the Mid-Atlantic Cordillera or Ridge considered the largest mountain range (aprox. $16000 \mathrm{~km}$ ) on Earth. It extends from the Arctic Ocean to near the southern tip of Africa. At this constructive plate boundary, new oceanic crust is generated each year at a spreading rate of about $2.5 \mathrm{~cm} / \mathrm{yr}$. Other features represent convergent margins, where the oceanic plates are consumed and recycled by the subduction factory (Tatsumi, 2005, Hacker et al., 2003a,b). In these regions, known as subduction zones, the trenches can reach staggering depths down to almost $11 \mathrm{~km}$ 
as measured in the planet's deepest point, the Challenger Deep situated in the Pacific Ocean's Mariana Trench (Stern et al 2003). In the latest expedition lead by Victor Vescovo, in 2019, the DSV Limiting Factor submarine dived down to 10,927 meters with almost $16 \mathrm{~m}$ lower than the previous descent in the trenches in 1960 (Morelle, 2019). The divergent and the convergent margins are only some of the main features, which can be spotted on the main bathymetric map. The others are the continental shelf, the continental slope, the continental rise, the abyss and the abyssal plain, the volcanic island arcs and off course, the seamounts and guyots (Fig. 1). Also, when an oceanic plate subducts, in the trench region, there is a sedimentary prism, formed by pelagic sediments. Its presence and thickness and whether or not tectonic erosion, sediment accretion or sediment subduction is taking place, will depend a lot on the tectonic regime and plate velocities.

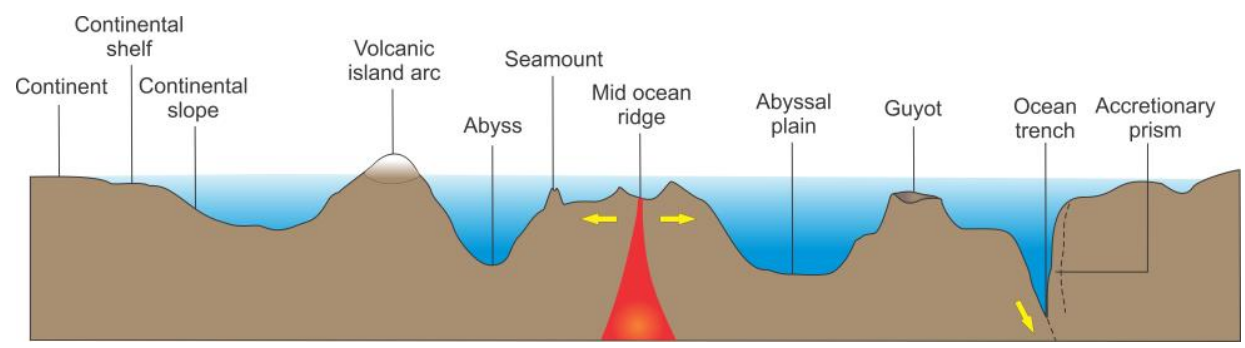

Figure 1 Main features of the ocean floor: continental shelf(1), continental slope (2), continental rise (3), mid-ocean ridge (4), ocean trench (5), volcanic island arc (6), abyss (7), abyssal plain (8), guyot (9), and seamount (10).

\section{SEAMOUNTS AND GUYOTS:} GENERAL CONSIDERATIONS

As can be observed in Fig. 2, the ocean floor is sprinkled with thousands of seamounts and guyots.
In 2011, Kim and Wessel made the first seamount census, presenting a list of more than 25000 potential seamounts. The database, referred to as KWSMTS v0.1 was generated based on the vertical gravity gradient VGG grid v16.1. (Fig. 2).

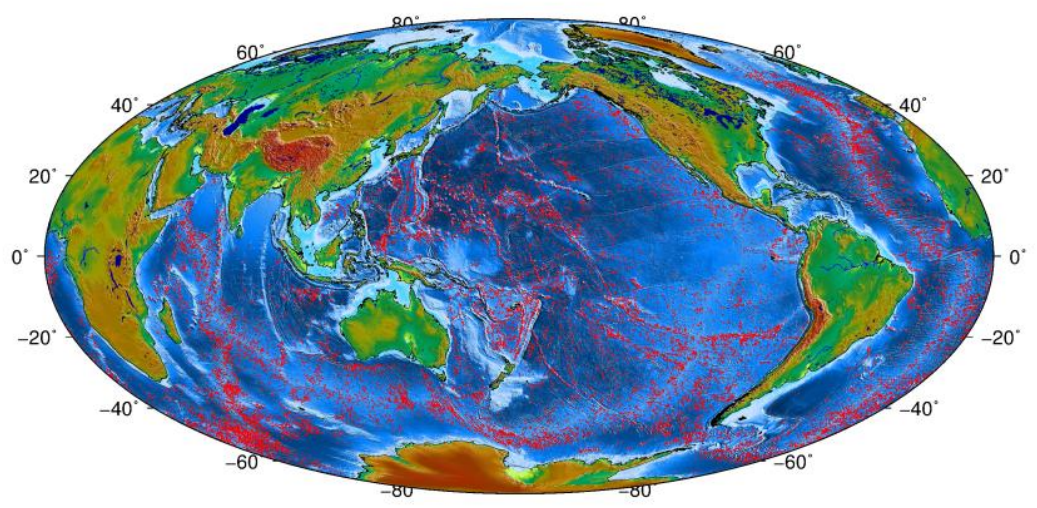

Figure 2 Seamounts global distribution. Red dots represent more than 24,500 potential seamounts from the entire ocean basins (Kim and Wessel, 2011). Topography/bathymetry 1 minute data from Smith and Sandwell (1997) were plotted in Hammer projection, using GMT (Generic Mapping Tools) software v. 5.4.3.

(Wessel and Smith, 1991, 1995, 1998)

By definition, a seamount (Fig. 3) is a large submarine volcanic mountain or any protuberance rising at least $1000 \mathrm{~m}$ above the surrounding ocean floor (Encyclopedia Britannica). Generally, a seamount is made of basalt, and its summit and flanks are covered in with marine sediment. Most of the seamounts are formed near mid-ocean ridges. Sometimes they can appear in the vicinity of mantle plumes or island arcs. The 3-D geometrical structure can vary from perfect cones to complex shapes (Straudigal \& Clouge, 2010). 


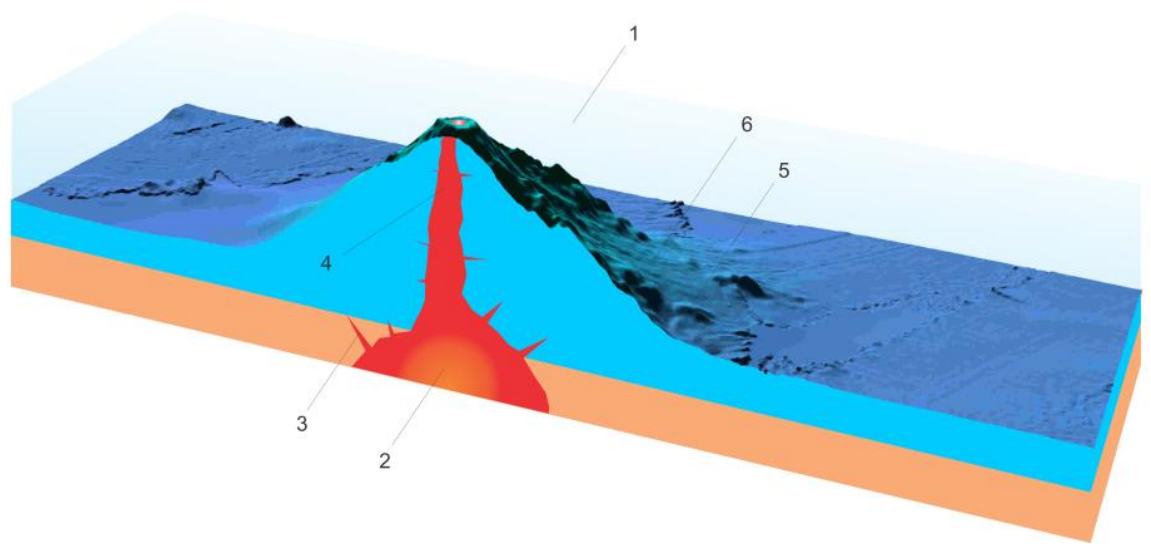

Figure 3 Diagram of a submarine seamount structure. (keys:

1. Water 2. Magma chamber 3. Dike 4. Magma conduit 5. Pillow lava 6. Lava flow.

A guyot, known in marine geology as a tablemount, is an isolated seamount of volcanic origin, with a flat top with diameters sometimes greater than $10 \mathrm{~km}$ (Fig. 4). They are found mainly in the Pacific Ocean, but sometimes they can be found in the Atlantic Ocean, too. They were first discovered by Harry Hess in 1945 and named after the American geologist Arnold Henry Guyot. They form at the ridge and then are shortened by atmospheric and/or wave erosion, by the time they migrate with the oceanic plate farther from the ridge.

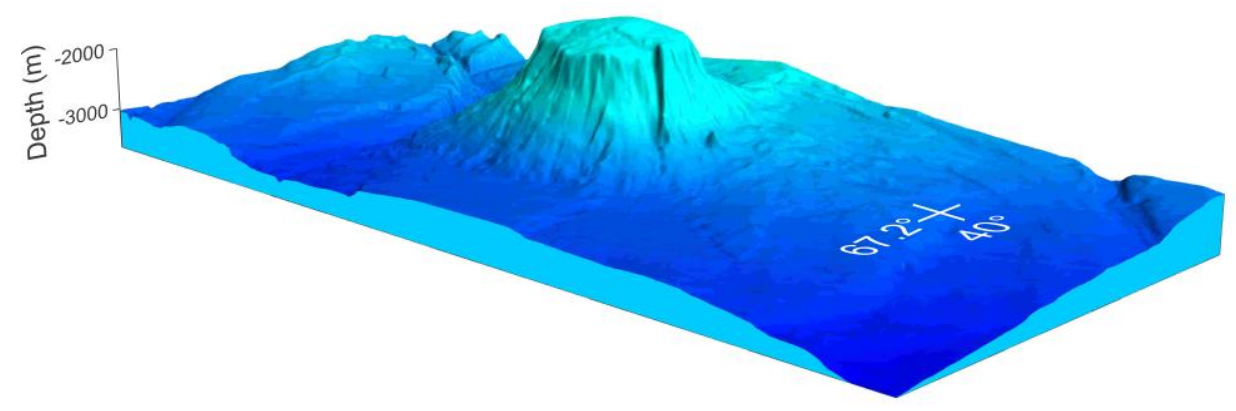

Figure 4 The Bear guyot or tablemount. Seamount DEM is created using Global Multi-Resolution Topography (GMRT) data source (Ryan et al., 2009).

These structures are the least explored morphological features and less than $0.1 \%$ were discovered using direct methods as echosounding or sampling through dragging, for instance. Most of the previously uncharted seamounts were discovered using indirect methods as the abovementioned method of Kim and Wessel (2011), based on satellite observations.

Some interesting data regarding the seamounts are related to their measurements. The HawaiianEmperor chain of $80 \mathrm{Ma}$ is considered the largest volcanic islands arc, with $6000 \mathrm{~km}$ length. From all the seamounts, Mauna Kea, which form part of the Hawai'i Emperor seamount chain, is the highest, with $4207 \mathrm{~m}$ above sea level and with a total height of $10100 \mathrm{~m}$, topping the Everest by far.

\section{SEAMOUNTS: GEODYNAMICAL RELEVANCE}

Observing the seamounts distribution on the ocean floor, it looks like they form patterns, frosting into the oceanic crust past movements. Some of them are as old as approximately 180-200 $\mathrm{Ma}$, and generally found in the west Pacific and north-west Atlantic (Müller, 2008), but others are even almost $270 \mathrm{Ma}$ up to $340 \mathrm{Ma}$ and located in the eastern Mediterranean Sea (Granot, 2016), as a remnant of the Tethys Ocean. 
In one of the most dramatic examples, the Hawaiian-Emperor chain bends almost $60^{\circ}$, and the explanation is an abrupt change in the motion of the Pacific Plate 47 Ma ago and/or a southward drift of the mantle plume continuously providing material to the chain (Torsvik et al., 2017). Both processes seem to have played an important geodynamic role and have to be considered together.

Even though they are formed near mid-ocean ridges or in the vicinity of mantle plumes or island arcs, sooner or later, the fate of the seamounts or guyots is inevitable: they will end up entering subduction and being recycled into the subduction factory (Hacker et al., 2003a). They are processed into magmas, which will erupt later through volcanism, generating continental crust, all this recycling process being of the outmost importance for the evolution of the solid Earth (Tatsumi, 2005). In a subduction factory, the correlation between the location of intermediate-depth earthquakes, the depth of low-velocity subducted crust, and the predicted location of hydrous minerals, was already established through numerical modelling, as the dehydration reactions are linked to intermediatedepth seismicity (Hacker et al., 2003b, Manea et al., 2004). On top of this, it is possible that the presence of seamounts or guyouts on the subducting plate will add further complications to the already complex subduction systems (Scholz and Small, 1997).

Once nearing the subduction system, the influence of seamounts commences. As Watts et al. (2015) observed, a seamount, once it enters a subduction zone, will affect the forearc morphology, the uplift history of the island arc, including the structure of the downgoing slab. Sometimes the seamounts can be accreted to the forearc or carried down into the subduction zone and recycled, maybe due to the tectonic regime specific for each subduction zone in particular. The accretionary wedge is deformed in many cases. Sometimes, the seamount will collapse and if an abyssal fault is reactivated at the trench, the seamount can be even parted in halves. The subduction of a seamount/guyout can have mechanical consequences with a special emphasis on the generation of large earthquakes. In 1976, Kelleher and McCann, concluded that the collision zone in which the seamounts subducts, there is an boosting effect on the seismic coupling (Scholz and Small, 1997). This is a direct consequence of the subduction of large seamounts that possibly increases locally the normal stress across the subduction interface.

The importance of studying the seamounts behavior in any stage of their development is related generally with the geological hazards generated: major explosive eruptions, large scale landslides generating tsunami or large earthquakes.

1st of April, 2014, was an important year, as a Mw 8.1 earthquake occurred in Iquique, rupturing an important portion of a seismic gap in northern Chile. Geersen et al. (2015) by analyzing the marine seismic reflection and swath bathymetric data observed that several under-thrusting seamounts correlate well with the limits of the seismic rupture. They linked the subduction of those seamounts to the reduced plate-coupling, by fracturing the overriding plate in the shallow subduction zone. The authors agree that the subducting seamounts control intermediate coupling and seismic rupture.

Sometimes, a segment of the subducted slab is dominated even by a $40 \%$ of seamounts, as it was observed in central Costa Rica (von Huene et al., 1995). The seamounts entering subduction generally mark furrows and domes on the continental slope (Ranero and von Huene, 2000; von Huene et al., 1995). Using 3-D P-wave velocity structure and petrological modelling, Husen et al. (2003) analyzed the Costa Rica subduction zone, and through tomographic imaging within the seamountdominated segment of the Cocos Plate they show that the structure is quite complex and a cluster of seismicity is associated to each of the anomalies. Interestingly, there was no sign of subducted seamounts at greater depths. As a seamount is formed mainly from highly altered, possible serpentinized and fractured oceanic crust, once subducted the buoyant mass will increase the normal stress, hence the occurrence of large subduction earthqukes (Cloos, 1992; Husen et al., 2002). Husen et al. (2003) conclude that by increasing the normal stress, it is possible also to reactivate the fractures associated with the formation of seamounts, producing a cluster of much smaller earthquakes in the vicinity of a subducted seamount. 
In a recent study, Baillard et al. (2018) show that it is possible to track subducted ridges inside a subduction zone using the intermediate-depth seismicity. By looking at the distribution of intermediate-depth seismicity they conclude that the uneven distribution of this kind of seismicity, and the presence of a seismic gap, previously related to a supposed tear in the slab, may be instead directly related to the subduction of a ridge. Also, Morton et al. (2018) analyzed a cluster of events detected by an amphibious seismic network in Cascadia and they detected two separate clusters of events, one near a subducted seamount, and the second one probably by an accreted seamount. They concluded that the earthquakes detected recently in the Cascadia Subduction zone are related both, to the subduction of seamounts and a deformed upper plate.

Other possible consequences of seamounts subduction are spatially related to slow slip and tremor occurrence, as it was shown by Barker et al. (2018) for the North Hikurangi Subduction zone, in New Zeeland. Slow slip events, or SSEs, are slow displacement episodes that can have durations up to several weeks or months. In New Zeeland, they discovered a subducted seamount covered in sediments, which triggered slowslip events only where the sediments were present, and not on the top of the subducted seamount. Also they proposed that the high fluid pressure within the subducted sediments might facilitate shallow slow slip. Recently, Bonnet et al. (2019) showed that when a seamount enters a subduction zone and maintains its integrity down to $\sim 30 \mathrm{~km}$ depth seamount does not behave as a large earthquake asperity but rather as a barrier.

The seamounts subduction, in regions where large seamount chains enter into subduction, can slow down even the mantle flow beneath the volcanic arcs, as was shown by Timm et al. (2013) in their work related to the subduction of the Louisville seamount chain beneath the central Tonga-Kermandec arc.

These represent only some key examples of the extensive research on seamount subduction. They clearly show that the presence of a singular seamount, or of many seamounts grouped in clusters or trails, will have a key influence on the long-term behavior of subduction zones. Seamounts can distort Wadatti-Beniof zones and also strongly affect the degree of mantle wedge hydration and the oceanic crust at least down to intermediate depths. Additionally, an important influence was observed even further down, where the mantle flow can be influenced locally by the subduction of these features.

\section{SEAMOUNT SUBDUCTION: ANALOGUE EXPERIMENTS}

Analogue experiments were performed in order to elucidate the fate of seamounts entering subduction and their possible implications on the mechanical behavior of the subduction zone. Researchers were interested mostly in the deformation patterns observed. Usually, the analogue models, will analyze the complex fracture network, taking into account a brittle/plastic rheology (Dominguez et al., 1998b, Wang and Bilek, 2011). Most of these experiments are based on classical sandbox modeling, in which the spatial-temporal deformation is compared with seismic images and bathymetry interpretation. Various authors tried to analogue modeling the subduction of a single seamount or plateau. They observed that the trench remained quasi-linear on each side of the plateau in the models with a stronger slab, but also some severe deformation at the front of the overriding plate, where seamounts or aseismic ridges subduct (Domingues et al., 1998b, 2000; Martinod et al., 2005). Sometimes the authors considered small conical-shape seamounts or guyots, other times trails of seamounts, but the accretion of seamounts was avoided. However, they were able to obtain a good correlation between the marine data and their experimental results, after a comparison with the well-studied Costa Rican seamount subduction zone. Beside the preferred setup where seamounts are perpendicular to the trench, the impact of oblique subduction of seafloor irregularities was also performed, with satisfying results (Dominguez et al., 1998a, Hampel et al., 2004, Zeumann and Hampel, 2015).

Recent analogue experiments (Wang at al., 2019) had a different approach and the attention was focused on the effect of seamount trails on the accretionary wedge in order to understand the deformation mechanisms affecting it. 
Anyhow, the main disadvantage of analogue modeling is related to the fact that thermal conditions cannot be imposed inside the sandbox, and from here, the necessity to consider other advanced modeling methods.

\section{SEAMOUNT SUBDUCTION: NUMERICAL MODELS}

As technology became more sophisticated, researchers tried to model numerically the seamount subduction and the possible implications resulting from this process. Those numerical models showed influence that a bathymetric height can have in a subduction zone, especially on the overriding plate: mineralization processes in the overriding plate, as shown in a 1-D model by Rosenbaum et al. (2005); uplift of the overriding plate, augmented subduction erosion and decrease in magma production, as in the 2-D models by Gerya et al., (2009); rotation of the overriding plate as in the 3-D models of Wallace et al. (2009). Some unsolved issues, were answered by Mason et al. (2010), when they performed 3-D numerical models in which revealed that the impact of buoyant oceanic plateau with a subduction zone may alter the trench behavior, regardless the slab and plateau rheology.

In recent years, Ruh et al. (2016) used advanced 3-D numerical techniques to investigate the evolution of crustal deformation and stress distribution within the upper plate induced by the underthrusting of subducting seamounts. The dynamical effects of the upper plate strength, subduction interface strength, and strain weakening of the crust are investigated. Results of numerical experiments are consistent with seismic reflection images and seismic velocity models of the upper plate in areas of seamount subduction along the Middle America Trench and give important insights into the long-lasting question, whether subducting seamounts and rough seafloor act as barriers or asperities for megathrust earthquakes. However, these were mechanical models, without including the equation of energy, of heat transport, in the modeling. Last year, during the International Joint
Workshop on Slow Earthquakes held in Fukuoka, Japan and the Latin America Academic Conference organized in Nikko, Japan, Manea (2018 a,b) showed for the first time 3-D numeric modeling results that incorporate both the mechanical and the thermal effects of seamount subduction. While this is work in progress, the preliminary results revealed that seamount subduction could produce significant temperature changes along the seismogenic interface, with implications for subduction earthquakes of paramount importance.

\section{SEAMOUNTS CLASSIFICATION}

Most studies tried to classify the seamounts for their biological importance (Clark et al., 2011) or from the mineral resources exploitation point of view (ISA, 2007), but here, the seamounts around the world are examined in a first attempt to classify them from their geodynamic relevance point of view. A special attention is given to the seamounts situated near subduction zones. This classification will be used later for numerical modeling their behavior once they enter into a subduction zone.

Straudigal \& Clouge (2010) consider that there are six main types of seamounts based on their geological evolution: small seamounts (100-1000-m height), mid-sized seamounts (>1000-m height, $>$ 700-m eruption depth), explosive seamounts (< 700-m eruption depth), ocean islands, extinct seamounts, and subducting seamounts. From the geodynamical point of view, the subducting seamounts are of upmost importance (Fig. 5).

As we classify seamounts entering subduction using their density on the subducted oceanic plate, their size and their integrity criterions (Fig. 6), another criteria which has to be taken into account is related to the existence of a root, and whether or not that root is serpentinized.

Also, it is important to consider if a seamount complex is affected by hydrothermal circulation. Based on this, some of them are considered hot and others cold, and heat production approximations in conjunction with heat flow observations will be used for better constrain the numeric models (Fig. 7). 


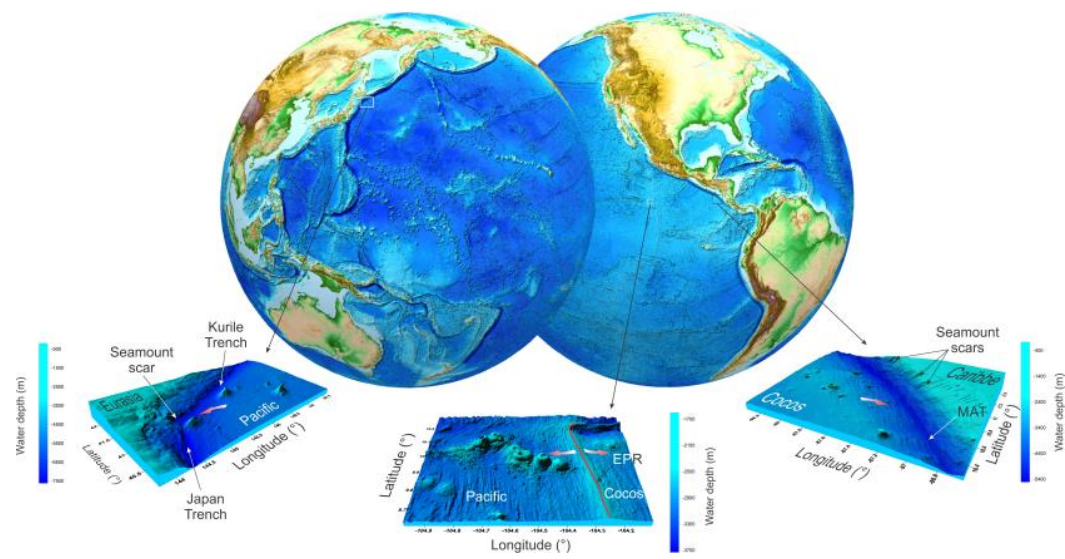

Figure 5 Top: Pacific and North America view angles of color-shaded global bathymetry and topography maps (ETOPO1 Global Relief Model dataset, Amante and Eakins (2009)). This figure was created with the open source software ParaView (http://www.paraview.org) version 5.6.0, licensed under the CC BY 4.0 license (https://creativecommons.org/licenses/by/4.0/).

Bottom: Three seamount regions are shown in detail corresponding to Japan and Kurile subduction zones, East Pacific Rise (EPR), and Middle America Trench (MAT). Red arrows show the movement of tectonic plates. Red curve corresponds to the location of EPR. Maps are created using global multi-resolution topography-bathymetry data from Ryan et al. (2009).

a)

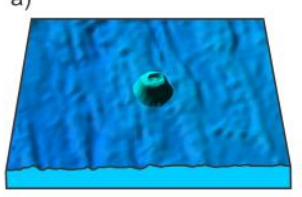

b)

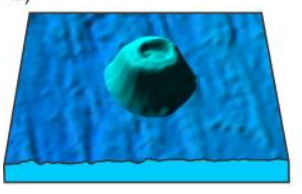

c)

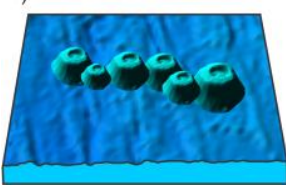

Figure 6 Different types of seamounts: a) Isolated single small and medium-size seamounts. b) Isolated single large-size seamounts. c) Seamount chains. d) Clusters of seamounts of different sizes. e) Seamount split in two by a spreading ridge (thick red line)f) Faulted seamount approaching a subduction zone.

\section{CONCLUSIONS}

There is an obvious advantage of performing a complex thermomechanical numerical modeling in order to understand the seamounts behavior. This is an initial effort to understand the long-term effect of seamount entering into subduction, but also serves for further advancing our understanding of oceanic plate irregularities impact on active subduction zones.

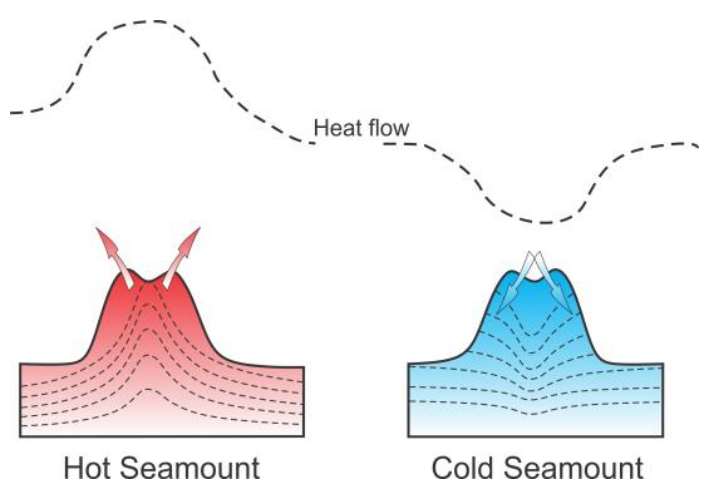

Figure 7 Seamounts temperature distribution as a function of hydrothermal circulation. Hot seamount refers to a seamount with an outflow water circulation. Cold seamount refers to a recharging seamount. Dashed curves inside the seamounts refer to hypothetical geotherms. Curved arrows show the water flow. Dashed curves add noted with "heat flow" show a theoretical heat flow distribution.

\section{Acknowledgements}

This work was supported by a grant of the Romanian Ministry of National Education and Scientific Research, RDI Program for Space Technology and Advanced Research - STAR, project ID 513. Also, Support from the Research Center for Urban Safety and Security, Kobe University, Japan was partially provided for this study. 


\section{REFERENCES}

Amante, C. and Eakins, B.W. (2009). ETOPO1 1 arcminute global relief model: procedures, data sources and analysis (p. 19). Colorado: US Department of Commerce, National Oceanic and Atmospheric Administration, National Environmental Satellite, Data, and Information Service, National Geophysical Data Center, Marine Geology and Geophysics Division

Baillard, C., Crawford, W.R., Ballu, V., Pelletier, B., and Garaebiti, E. (2018). Tracking subducted ridges through intermediate-depth sesimicity in the Vanuatu subduction zone. Geology, 46 (9): 767-770. doi:10.1130/G45010.1

Barker, S.H.N., Henrys, S., Caratori Tontini, F., Barnes, P.M., Bassett, D., Todd, E., and Wallace, L. (2018). Geophysical constraints on the relationship between seamount subduction, slow slip, and tremor at the North Hikurangi subduction zone, New Zealand. Geophysical Research Letters, 45, 12804-12813. doi: 10.1029/2018GL080259.

Bonnet, G., Agard, P., Angiboust, S., Fournier, M., and Omrani, J. (2019). No large earthquakes in fully exposed subducted seamount. Geology, 47(5), 407410. doi:10.1130/G45564.1.

Clark, M.R., Watling, L., Rowden, A.A., Guinotte, J.M., Smith, C.R. (2011). A global seamount classification to aid the scientific design of marine protected area networks, Ocean \& Coastal Management, vol. 54 (1), 19-36, ISSN 0964-5691, doi: 10.1016/j.ocecoaman.2010.10.006

Cloos M. (1992). Thrust-type subduction-zone earthquakes and seamount asperities: a physical model for seismic rupture, Geology, 20, 601-604.

Coatu, N. (1986). Legende Populare geografice: locuri si legende. Bucuresti: Editura Sport-turism.

Densuşianu, O. (1910), Tradiţii şi legende populare, Bucureşti, Editura L. Alcalay.

Dominguez, S., Lallemand, S., Malavieille, J., and Schnurle, P. (1998a). Oblique subduction of the Gagua Ridge beneath the Ryukyu accretionary wedge system: Insights from marine observations and sandbox experiments, Marine Geophysical Research, 20(5), 383-402.

Dominquez, S., Lallemand, S., Malavieille, J., von Huene, R. (1998b). Upper plate deformation associated with seamount subduction. Tectonophysics, 293 (3-4), 207-224. doi: 10.1016/S0040-1951(98)00086-9

Dominguez, S., Malavieille, J., Lallemand, S.E. (2000). Deformation of accretionary wedges in response to seamount subduction: insights from sandbox experiments. Tectonics 19 (1), 182-196.

Eliade, M. (1978). Aspecte ale mitului, Bucureşti, Editura Univers. Encyclopaedia Britannica https://www.britannica.com/science/seamount\#ref142 69
Fox, M. (1994). Gods and Heroes: the story of Greek mythology. Michael O'Mara Books Ltd, London. ISBN:978-1-85479-103-0

Geersen, J., Ranero, C.R., Barckhausen, U., and Reichert, C. (2015). Subducting seamounts control interplate coupling and seismic rupture in the 2017 Iquique earthquake area. Nature Communications, 6 (8267), doi: $10.1038 /$ ncomms9267.

Gerya, T.V., Fossati, D., Cantieni, C., and Seward, D. (2009). Dynamic effects of aseismic ridge subduction: numerical modelling. European Journal of Mineralogy 21 (3), 649-661.

Granot, R. (2016). Palaeozoic oceanic crust preserved beneath the eastern Mediterranean. Nature Geoscience, doi: 10.1038/ngeo2784

Hacker, B.R., Abbers, G.A., and Peacock, S.M. (2003). Subduction Factory 1. Theoretical mineralogy, densities, seismic wave speeds, and $\mathrm{H} 2 \mathrm{O}$ contents. Journal of Geophysical Research, vol. 108, no. B1, 2029. doi: 10.1029/2001JB001127.

Hacker, B.R., Peacock, S.M., Abers, G.A., and Jolloway, S.D. (2003). Subduction Factory 2. Are intermediatedepth earthquakes in subducting slabs linked to metamorphic dehydration reactions? Journal of Geophysical Research, vol. 108, no B1, 2030, doi: 10.1029/2001JB001129.

Hampel, A., Adam, J., and Kukowski, N. (2004). Response of the tectonically erosive south Peruvian forearc to subduction of the Nazca Ridge: Analysis of three-dimensional analogue experiments, Tectonics, 23, TC5003, doi:10.1029/2003TC001585.

Husen, S., Quintero, R., Kissling, E. (2002). Tomographic evidence for a subducted seamountbeneath the Gulf of Nicoya, Costa Rica: the cause of the $1990 \mathrm{Mw}=7.0$ Gulf of Nicoya earthquake, Geophys. Res. Lett., 29, doi: 10.129/ 2001 GL014 045.

ISA (2007). Polymetallic sulphides and cobalt-rich ferromanganese crusts deposits: establishment of environmental baselines and an associated monitoring programme during exploration. In: Proceedings of the international seabed authority's workshop, [chapter 13]. p. 295-308.

Kim, S.-S. and Wessel, P. (2011). New global seamount census from the altimetry-derived gravity data, Geophysical Journal International, 186, 615-631, doi: 10.1111/j.1365-246X.2011.05076.x

Manea, V.C., Manea, M., Kostoglodov, V., Currie, C.A., and Sewell, G. (2004). ThermalStructure, Coupling, and Metamorphim in the Mexican Subduction Zone beneath Guerrero, Geophysical Journal International, vol. 158, pp. 775-784, doi: 10.1111/j.1365246X.2004.02325.x

Manea, V.C. (2018a). Slow-slips and tectonic tremors diversity in subduction zones. Chile-Japan Academic Forum 2018 in Nikko, Japan.

Manea, V.C. (2018b). Slow-slips and tectonic tremors diversity in subduction zones. International Joint Workshop on Slow Earthquakes 2018, Fukuoka, Japon, 
Martinod, J., Funiciello, F., Faccenna, C., Labanieh, S., Regard, V. (2005). Dynamical effects of subducting ridges: insights from 3-D laboratory models. Geophysical Journal International 163 (3), 11371150.

Mason, W.G., Moresi, L., Betts, P.G., and Miller, M.S. (2010). Three-dimensional numerical models of the influence of a buoyant oceanic plateau on subduction zones Tectonophysics, 483, 71-79 doi: 10.1016/j.tecto.2009.08.021

Morelle, R. (2019). Mariana Trench: deepest-ever sub dive finds plastic bag. BBC News: https://www.bbc. com/news/science-environment-48230157

Morton, E.A., Bilek, S.L., and Rowe C.A. (2018). Newly detected earthquakes in the Cascadia subduction zone linked to seamount subduction and deformed upper plate. Geology, 46 (11): 943-946. doi: $10.1130 / \mathrm{G} 45354.1$

Müller, R.D. (2008). Age, spreading rates, and spreading asymmetry of the world's ocean crust. Geochemistry, Geophysics, Geosystems. 9 (4): Q04006. doi:10.1029/2007GC001743

Pittman, R.S. (1954). A grammar of Tetelcingo (Morelos) Nahuatl. Language, vol. 30, no. 1, Part 2: Language Dissertation no. 50, Linguistic Society of America (ed), : https://www.jstor.org/stable/522207

Rosenbaum, G., Giles, D., Saxon, M., Betts, P.G., Weinberg, R.F., Duboz, C. (2005). Subduction of the Nazca Ridge and the Inca Plateau: insights into the formation of ore deposits in Peru. Earth and Planetary Science Letters 239 (1-2), 18-32.

Ruh, J, Sallares, V., Ranero, C.R., and Gerya, T. (2016). Crustal deformation dynamics and stress evolution during seamount subduction: High-resolution 3- D numerical modeling. Journal of Geophysical Research: Solid Earth, 121, 6880-6902

https://doi.org/10.1002/2016JB013250

Ryan, W.B.F., Carbotte, S.M., Coplan, J.O., S., O'Hara, Melkonian, A., Arko, R., Weissel, R.A., Ferrini, V., Goodwillie, A., Nitsche, Bonczkowski, J., and Zemsky, R. (2009). Global Multi-Resolution Topography synthesis, Geochem. Geophys. Geosyst., 10, Q03014, doi: 10.1029/2008GC002332

Scholz, C. and Small, C. (1997). The effect of seamount subduction on seismic coupling. Geology, vol 25(6), pp. 4870490. httpd://doi.org/10.1130/0091-7613.

Ranero, C.R. and Von Huene, R. (2000). Subduction erosion along the Middle America convergent margin, Nature , 404, 748-752.

Smith, W.H.F., and Sandwell, D.T. (1997). Global seafloor topography from satellite altimetry and ship depth soundings, Science, v. 277, p. 1957-1962.

Stern, R.J., Fouch, M.J., and Klemperer, S.L. (2003). An Overview of the Izu-Bonin-Mariana Subduction Factory. in Inside de Subduction Factory, AGU Geophysical Monograph 138, pp. 175-222. doi: 10.1029/138GM10
Straudigal, H. and Clauge, D.A. (2010). The Geological History of Deep-Sea Volcanoes: Biosphere, Hydrosphere, and Lithosphere Interactions, Oceanography. Seamounts Special Issue. vol 23 (1)

Tatsumi, Y. (2005). The Subduction Factory: How it operates on Earth, GSA Today. 15 (7): 4-10. doi:10.1130/1052-5173

Timm, C., Bassett, D., Graham, I.J., Leybourne, M., I., de Ronde, C.E.J., Woodhead, J., Matthews, D.L., and Watts, A. (2013). Louisville seamount subduction and its implications on mantle flow beneath the central Tonga-Kermandec arc. Nature Communications, 4 (1720). doi: 10.1038/ ncomm2702.

Torsvik, T.H., Pavel V. Doubrovine, P.V., Steinberger, B., Gaina, C., Spakman, W., Domeier, M. (2017). Pacific plate motion change caused the HawaiianEmperor Bend. Nature Communications, 8: 15660 DOI: $10.1038 /$ ncomms 15660

Von Huene R. et al., (1995). Morphotectonic features of the Costa Rican Pacific margin surveyed during Sonne 76 cruise, in Geologic and Tectonic Development of the Caribbean Plate Boundary in Southern Central America, pp. 291-308, ed. Mann P., Geological Society of America, Boulder.

Wallace, L.M., Ellis, S., Mann, P. (2009). Collisional model for rapid fore-arc block rotations, arc curvature, and episodic back-arc rifting in subduction settings. Geochemistry Geophysics Geosystems 10 (5). doi:10.1029/2008GC002220.

Wang, C., Ding, W., Li, J., Dong, C., and Fang., Y. (2019). Effects of multi-seamounts subduction on accretionary wedge deformation: insights from analogue modelling. EGU2019-3264, Geophysical Research Abstracts, vol. 1

Wang, K.L., and Bilek, S.L. (2011). Do subducting seamounts generate or stop large earthquakes? Geology, 39(9), 819-822.

Watts, A.B., A.A.P. Koppers, and D.P. Robinson. 2010. Seamount subduction and earthquakes. Oceanography 23(1):166-173, https://doi.org/ 10.5670/oceanog.2010.68.

Wessel, P. and Smith, W.H.F. (1991). Free software helps map and display data, EOS Trans. AGU, 72, 441-446.

Wessel, P. and Smith, W.H.F. (1995). New version of the Generic Mapping Tools released, EOS Trans. AGU, 76, 329-336.

Wessel, P. and Smith, W.H.F. (1998). New, improved version of Generic Mapping Tools released, Eos Trans, AGU, 79, 579.

Zeumann, S. and Hampel, A. (2015). Deformation of erosive and accretive forearcs during subduction of migrating and non-migrating aseismic ridges: Results from 3-D finite element models and application to the Central American, Peruvian, and Ryukyu margins, Tectonics, 34(9), 1769-1791, doi:10.1002/ 2015 TC003867. 